\title{
e-Governance through e-Seva in Tamilnadu
}

\author{
C. R. Senthilnathan, V.Dhayalan
}

\begin{abstract}
---e-governancele-seva has became a key mantra for the governments to improve their services to the general public after the advancement of Information and communication technology (ICT). India being one of the developing countries, has initiated their ICT services in the form of eSava. Though government started these services in India about four year ago, this study is initiated to find the consumers perception on the eSevacentres and the gaps in the consumer expectations. Three constructs namely, system stability, service reliability and service quality are used in the study to measure the satisfaction. It is found that of the three measures, system stability and service quality have less positive impacts on consumer satisfaction indicating that definitely the government has to improve their service. Whereas the service reliability is better as far as the satisfaction level of the consumers concerned.
\end{abstract}

Keywords: eSeva, Consumer perception, ICT, Service quality.

\section{INTRODUCTION}

e-governance / e-seva is all about the implementation of the government in administration, support public services and creating relationship among its citizens. Government usage of ICT is to create governmental policies, norms and regulations and thereby to manage and monitor its governance is known as e-governance (Palvia\& across Pan India, one should take into consideration the ground level realities in accessing internet in the villages of India (Malhotra.C.,Chariar.V, Das .L (2010)).

Like any other developing countries, India also faces many major hurdles and oppositions in the implementation of ICT in various government sectors (Mistry.H (2010), Dwivedi (2010). S.K, Kumar.S.P (2010)), The reason for these inadequacies is defiance in finance, lack of motivation and awareness, lack of trust, and lack in technical design. Some of the previous studies (Rajagopalan.R,(2008), major problem in Indian e-governance is that it is not citizen centric and suggest that it should be citizen and more specific community centric and duly understanding the local needs and their demands.

One of the major vision projects of Indian Government is to enable all Government services with information technology which will enable accessibility to every man in the Indian village in a more efficient and reliable way. The vision project name is e-Sevai meaning service through electronic media.

\section{OBJECTIVES AND SCOPE OF THE STUDY}

- To study the consumer perception on eSavai service

Revised Manuscript Received on 14 August, 2019.

Dr. C.R.Senthilnathan, Associate Professor, Sri Sairam Institute of Technology, Chennai, Tamilnadu, India.

Dr.V.Dhayalan, Asst. Professor, Sairam Institute of Management Studies, Chennai, Tamilnadu, India. information and communication technologies (ICT) to help Sharma,(2007)). Before the implementation of e-governance Guma.P.K(2013), Odat.A.M,(2012)) have identified that

\section{- To find the extent of consumer satisfaction}

This study will help in identifying the satisfaction level of the consumer and would help in rectifying the lacuna in the service procedures. This will also bring out the consumer expectations which can be addressed in near future for enhancing the consumer satisfaction.

\section{REVIEW OF LITERATURE}

In the economy wise classification, one among the top states is Tamilnadu. Tamilnadu has enabled many of its services through the e-seva platform (Kumar et al.,2017). Over the years the public interest has increased dramatically in the use of ICT and e-technology is the solution for this. Today, e-governance plays an importance role in transforming the political, social and economical landscape of an economy. The success of the implementation of ICT by the government is not as easy as it looks. The success of implementation includes other important factors like cultural values and attitude within the government and its ethics (Asgarkhani .Mehdi, 2005).

\section{METHODOLOGY}

The sample size of the current study is 206 with the respondents selected at simple random technique with a well structured questionnaire. Five point likertscale is used to access the responses of the respondents. To statistically analyse the data, SmartPLS software is used.

\section{CONCEPTUAL FRAMEWORK}

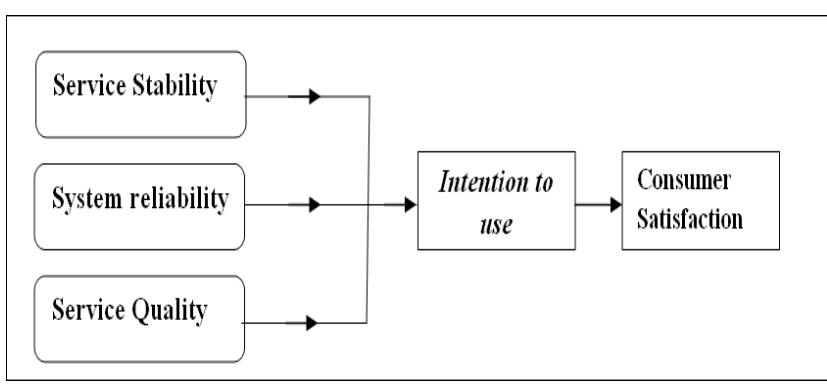

The major two objectives of any government is to convey the relevant information to the general public and to increase the level of transparency of the government functioning. (Ma,Chung et al., 2005). A good government system's goal should be to provide the required, reliable, useful and timely information service which is easily accessible to all the people.(Baker, 2009). The three major dimensions which determine the satisfaction level of e-seva (eGovernance) users are service quality, system reliability and stability. Service quality refers to all the services at the one-stop service centre like the birth/death, income, community
Blue Eyes Intelligence Engineering

\& Sciences Publication 


\section{e-Governance through e-Seva in Tamilnadu}

certificateetc,. System reliability is the eSavai service provider's ability to provide accurate and dependable service to the consumers. Also it includes the government policy on the consumers' personal data protection. The success of the eSevaicentres mainly depends on the perception of the consumers about the service they receive from the service personnel. Knowing the importance of these three constructs the below mentioned three hypotheses were formulated.

$\mathrm{H}_{01}$ : Service satiability has a positive effective on consumer satisfaction

Table 1

\begin{tabular}{|c|c|c|c|c|c|}
\hline Gender & $\begin{array}{l}\text { Male } \\
\text { Female }\end{array}$ & $\begin{array}{l}68 \% \\
32 \%\end{array}$ & Occupation & $\begin{array}{l}\text { Government } \\
\text { Private } \\
\text { Others } \\
\end{array}$ & $\begin{array}{l}13.4 \% \\
37.8 \% \\
48.8 \% \\
\end{array}$ \\
\hline Age & $\begin{array}{l}<20 \\
20-30 \\
30-45 \\
>45\end{array}$ & $\begin{array}{l}2.3 \% \\
62.5 \% \\
23.8 \% \\
11.4 \%\end{array}$ & Education & $\begin{array}{l}\text { High school } \\
\text { Graduate } \\
\text { Others }\end{array}$ & $\begin{array}{l}21.1 \% \\
69.2 \% \\
9.7 \%\end{array}$ \\
\hline
\end{tabular}

\section{MEASUREMENT MODEL ANALYSIS}

The data for the constructs were examined for convergent, discriminant validity and reliability. The table 2 shows the constructs loading well above the required value, ie, .40 (Hair et al.,2013). The values of the average variance extracted were also well greater than .50 (Fornell\&Larcker, 1981). This shows that the convergent validity is true. Also

\section{Table 2}

$\mathrm{H}_{02}$ : System reliability has a positive effective on consumer satisfaction

$\mathrm{H}_{03}$ :Service quality has a positive effective on consumer satisfaction

\section{DATA ANALYSIS AND INTERPRETATION}

Of the sample data collected, $68 \%$ of them were male, $62.5 \%$ of the sample were in the age group $20-30$ years old, $48.8 \%$ of the respondents were neither working in government nor private and $69.2 \%$ of them were graduates (Table 1). overall reliability of all the items taken together were greate than the tabulated value of 0.70 (Hair et al., 2013), indicating construct reliability. By comparing the correlation of square root values of AVEs, the discriminant validity is examined (Fornell\&Larcker, 1981). The table 3 indicates the square root values of the AVE of every item greater than its correlation values with every other item, thereby proving the constructs discriminant validity.

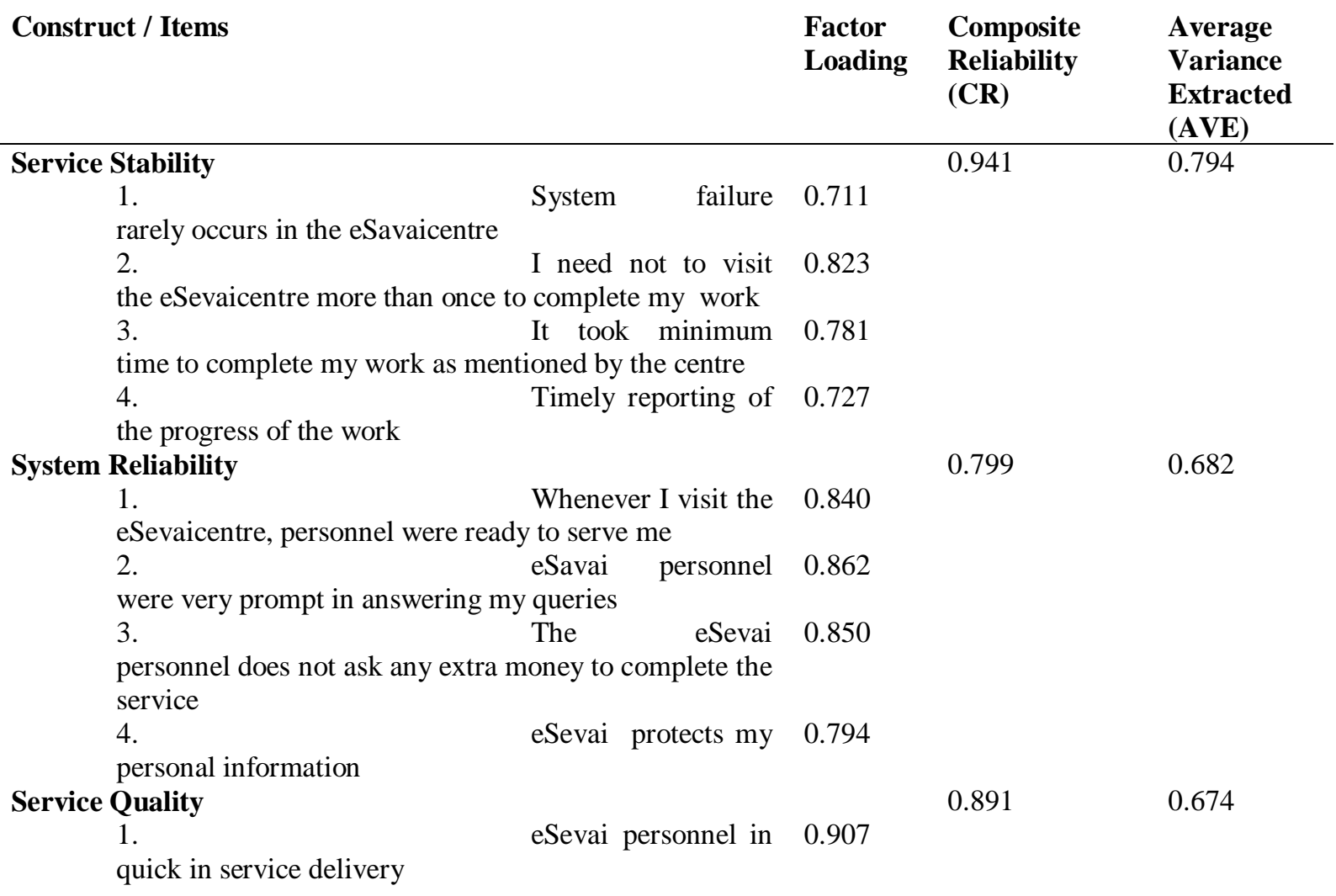




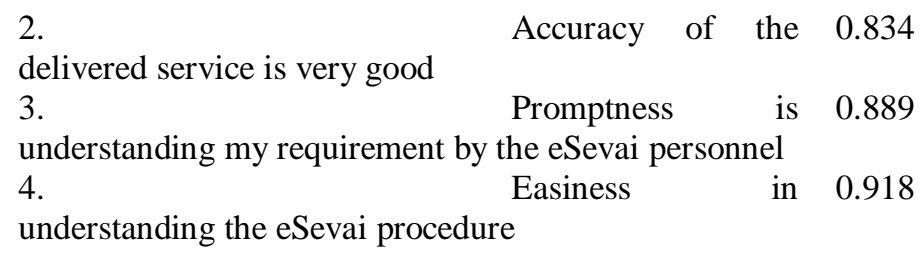

$\underline{\text { Table } 3}$

\begin{tabular}{lllll}
\hline & Service Stability & System Reliability & Service Quality & $\begin{array}{l}\text { Consumer } \\
\text { Satisfaction }\end{array}$ \\
$\begin{array}{l}\text { Service Stability } \\
\text { System Reliability }\end{array}$ & 0.608 & & & \\
Service Quality & 0.621 & $(0.888)$ & & \\
Consumer & 0.513 & 0.623 & $(0.825)$ & \\
Satisfaction & & 0.408 & 0.545 & $(0.947)$
\end{tabular}

Satisfaction

The main diagonal shows the constructs correlations with the square root of AVE

\section{STRUCTURAL MODEL ANALYSIS\& RESULTS}

A collinearity test is used to check whether constructs are highly correlated to each other. Table 4 shows the VIF values of all the constructs. It is observed that the values are above the minimum threshold value of 3.3 showing that there is no collinearity among the factors/constructs (Diamantopoulous and Siguaw, 2006).

Table 4

\begin{tabular}{lccc} 
Constructs & Weights & t-value & VIF \\
\hline Service Stability & 0.314 & 13.071 & 1.132 \\
System Reliability & 0.306 & 14.026 & 1.600 \\
Service Quality & 0.402 & 11.483 & 1.274 \\
Consumer & 0.335 & 8.085 & 1.369 \\
Satisfaction & & &
\end{tabular}

\section{HYPOTHESIS TESTING}

As per the procedure, a bootstrapping sample of 5000 was considered to assess the hypothesis relationship between the constructs. The outcome of the assessment explains that the 3 exogenous constructs collectively explains about $68 \%$ of the variance in consumer satisfaction (endogenous construct). The values of effect size of all the endogenous constructs were tested to find the impact of exogenous construct on it (Hair et al,.2013). To determine the magnitude of the effect on the endogenous constructs, the guidelines of Cohen's (1988) were used. It was found that the $\left(f^{2}\right)$ values are 0.17 and 0.16 for Service Stability and Service Quality suggesting a medium effect and 0.29 for System Reliability suggesting somewhat a large effect on the consumer satisfaction.

\section{CONCLUSION}

Tamilnadu government has successfully started its ICT project all over the state. Much as been debated about state's use of ICT in its day-to-day services through the eSevaicentre. To understand the perception of the consumers regarding the functionality of the eSevaicentre, this study is been initiated. Three key constructs were used and it is observed that out of the three constructs, service stability and service quality had relatively less positive impacts on consumer satisfaction indicating that definitely the government has to improve in these areas and the system reliability is better as far as the satisfaction of the consumers. Thus the study suggests the government agencies to concentrate on the lacuna and improve their service to the Tamilnadu general public and make the eSavaicentre a grand success.

\section{REFERENCES}

1. Asgarkhani . Mehdi, 2005, 'The Effectiveness of eService in Local Government: A Case Study' , 'The Electronic Journal of eGovernment', Volume 3 Issue 4, Pp 157-166.

2. Baker, D.L. 2009, 'Advancing e-Government performance in the United States through enhanced usability benchmarks', ' Government Information Quarterly', Volume 26(1),Pp 82-88.

3. Bannister, F., \& Connolly, R. (2012). Forward to the past: Lessons for the future of e-government from the story so far. Information Polity, Pp 211-226.

4. Bhatnagar, S. C., \& Singh, N. (2010). Assessing the Impact of E-Government: A Study of Projects in India. Information Technologies \& International Development, Pp 109-127.

5. Diamantopoulos. Adamantios and Judy A. Siguaw,2006, 'Formative Versus Reflective Indicators in Organizational Measure Development: A Comparison and Empirical Illustration', British Journal of Management', Volume 17, issue 4 Pp 263-282.

6. Dwivedi, S. K., \& Bharti, A. K. (2010). E-Governance in India- Problems and Acceptability. Journal of Theoretical and Applied Information Technology, 37-43.Gajendra, S., Xi, B., \& Wang, Q. (2012). E-overnment: Public Participation and Ethical Issues. Journal of EGovernance, 195-204.

7. Fornell .Claes and Larcker. David F, 1981, 'Evaluating Structural Equation Models with Unobservable Variables and Measurement Error', 'Journal of Marketing Research', Volume. 18, No. 1,Pp. 39-50.

8. Guma, P. K. (2013). Public-Sector Reform, E- 
Government and the Search for Excellence in Africa: Experiences from Uganda. Electronic Journal of eGovernment, Pp 241-252.

9. Hair, Joseph F. , Ringle, Christian and Sarstedt, Marko,2013, 'Partial Least Squares Structural Equation Modeling: Rigorous Applications, Better Results and Higher Acceptance', 'Long Range Planning' 46(1-2),Pp $1-12$.

10. Kumar.D and Panchanatham.N (2017),' 'A Study on ETransactions in E-Governance of Tamil Nadu', 'International Journal of Pure and Applied Mathematics' , Volume 116 No 22 Pp 81-88.

11. Kumar, S. P., Umashankar, C., Rani, J. K., \& Ramana, V. (2010). e-Governance Applications for citizens Issues and Framework. International Journal on Computer Science and Engineering, Pp 2362-2365.

12. Ma, L., Chung, J., \& Thorson, S.,2005, 'E-government in China: Bringing economic development through administrative reform', 'Government Information Quarterly', Volume 22(1), Pp 20-37.

13. Mistry, H. (2010). e-Governance: Efficiency and Challenges in India. Mumbai: Mahindra Special Services Group.

14. Odat, A. M. (2012). E-Government in Developing Countries: Framework of Challenges and Opportunities. Journal of Theoretical and Applied Information Technology, Pp 1013-1021.

15. Rajagoplan, R., \& Sarkar, R. (2008). Digital Networks and Sustainability: Do we need the Government? IEEE, Pp 49-54. 